\title{
A Synthetic Triple Helical Collagen Peptide as a New Agonist for Flow Cytometric Measurement of GPVI- Specific Platelet Activation
}

Citation for published version (APA):

Sang, Y., Huskens, D., Wichapong, K., de Laat, B., Nicolaes, G. A. F., \& Roest, M. (2019). A Synthetic Triple Helical Collagen Peptide as a New Agonist for Flow Cytometric Measurement of GPVI-Specific Platelet Activation. Thrombosis and Haemostasis, 119(12), 2005-2013. https://doi.org/10.1055/s-00391697660

Document status and date:

Published: 01/12/2019

DOI:

10.1055/s-0039-1697660

Document Version:

Publisher's PDF, also known as Version of record

Document license:

Taverne

Please check the document version of this publication:

- A submitted manuscript is the version of the article upon submission and before peer-review. There can be important differences between the submitted version and the official published version of record.

People interested in the research are advised to contact the author for the final version of the publication, or visit the DOI to the publisher's website.

- The final author version and the galley proof are versions of the publication after peer review.

- The final published version features the final layout of the paper including the volume, issue and page numbers.

Link to publication

\footnotetext{
General rights rights.

- You may freely distribute the URL identifying the publication in the public portal. please follow below link for the End User Agreement:

www.umlib.nl/taverne-license

Take down policy

If you believe that this document breaches copyright please contact us at:

repository@maastrichtuniversity.nl

providing details and we will investigate your claim.
}

Copyright and moral rights for the publications made accessible in the public portal are retained by the authors and/or other copyright owners and it is a condition of accessing publications that users recognise and abide by the legal requirements associated with these

- Users may download and print one copy of any publication from the public portal for the purpose of private study or research.

- You may not further distribute the material or use it for any profit-making activity or commercial gain

If the publication is distributed under the terms of Article 25fa of the Dutch Copyright Act, indicated by the "Taverne" license above, 


\title{
A Synthetic Triple Helical Collagen Peptide as a New Agonist for Flow Cytometric Measurement of GPVI-Specific Platelet Activation
}

\author{
Yaqiu Sang ${ }^{1,2}$ Dana Huskens ${ }^{1,2}$ Kanin Wichapong ${ }^{1}$ Bas de Laat ${ }^{1,2}$ Gerry A. F. Nicolaes ${ }^{1}$ \\ Mark Roest ${ }^{1,2}$
}

${ }^{1}$ Department of Biochemistry, Cardiovascular Research Institute
Maastricht (CARIM), Maastricht University, Maastricht,
The Netherlands
${ }^{2}$ Synapse Research Institute, Maastricht, The Netherlands

Address for correspondence Mark Roest, PhD, Oxfordlaan 70, Synapse, 6229EV, Maastricht, The Netherlands (e-mail: M.Roest@thrombin.com).

Thromb Haemost 2019;119:2005-2013.

\begin{abstract}
Synthetic cross-linked collagen-related peptide (CRP-XL) is a glycoprotein VI (GPVI) receptor activator for platelet activation. This triple helical peptide, widely used in platelet function tests, is synthesized and cross-linked through cysteine residues at its $\mathrm{N}$-terminus and C-terminus. Currently, there is only one laboratory, which is capable to produce this valuable peptide for clinical applications. In an attempt to provide a standardized alternative for CRP-XL, we developed a synthetic triple helical collagen peptide (STH-CP) with the same primary sequence as CRP-XL (GPC-(GPO) ${ }_{10}$-GPCGamide $)_{3}$, which was both on the $\mathrm{C}$-terminus and on the $\mathrm{N}$-terminus fixed on a scaffold with a binding side for each of the three peptides. The performance of STH-CP on platelet function was studied using flow cytometry and compared with CRP-XL. We found that platelet activation pattern in response to STH-CP and CRP-XL is similar, although the STH-CP requires sixfold higher concentrations to activate platelets to the same state. The intra-assay percent coefficient of variation of STH-CP and CRP-XL were both $<5 \%$ and the interindividual variation measured in 118 individuals for both peptides was around 23 and $21 \%$ for $\alpha$ llb $\beta 3$ activation and P-selectin expression,

Keywords

- platelet activation

- cross-linked collagenrelated peptide

- synthetic triple helical collagen peptide respectively. The STH-CP in ready-to-use reaction mix has lower variation than CRP-XL over 1-year storage. In reference values and seasonal variation study, the platelet activation response showed a strong correlation between STH-CP and CRP-XL.

Our findings show that this new STH-CP is a stable and potent platelet GPVI agonist which can induce the same reproducible platelet activation as CRP-XL and that STH-CP can be considered as a good alternative for CRP-XL.
\end{abstract}

\section{Introduction}

Under physiological conditions, platelets circulate in a resting state in blood. Upon vessel wall injury, platelets rapidly respond by adhering to the exposed subendothelial collagen, followed by platelet-platelet interaction and platelet activa- tion to form a plug that effectively seals the injured vessel wall to prevent excessive blood loss. ${ }^{1}$ Thus, one of the crucial initial steps in hemostasis is the interaction between platelets and collagen which results in platelet activation.

Despite decades of research, there is still no adequate and generally accepted platelet function test platform in routine received

April 30, 2019

accepted after revision

August 1, 2019 (c) 2019 Georg Thieme Verlag KG Stuttgart · New York
DOI https://doi.org/ 10.1055/s-0039-1697660. ISSN 0340-6245. 
diagnostic laboratories that covers the needs for platelet function diagnostics. Light transmission aggregometry (LTA) has been considered as the gold standard for many decades. ${ }^{2}$ In brief, LTA measures the changes in light transmission of platelet-rich plasma upon stimulation with different platelet agonists. One of the standard agonists used is collagen, native type I fibrils isolated from Achilles tendon of horses. This type of collagen only partly represents the collagen properties of collagen in the vessel wall, which makes the relevance of this agonist disputable. Also, the extraction process of collagen from its biological source may lead to loss of its fibrillar structure, which may result in unstable reactivity. ${ }^{3}$ Several other techniques have been proposed to replace LTA as gold standard for bleeding diagnostics, including Multiplate, PFA-100, TEG, or ROTEM. Validation studies have, however, shown that these techniques lack the specificity to replace LTA in bleeding diagnostics. ${ }^{4}$ Still, they may be of additional value to LTA, because they give a more global overview of platelet function. In addition to LTA, flow cytometry is another platelet function measurement that can be used for specific detection of platelet function disorders. ${ }^{5,6}$

The collagen fibers, which are the standard in LTA, cannot be used in flow cytometry, because they form a surface for platelet aggregation, which obstructs the individual cell measurements in flow cytometry. To increase the specificity of the collagen-specific pathways, the flow cytometry-based platelet activation requires receptor-specific agonists.

Efforts have been made to develop specific agonists to glycoprotein (GP) VI, which is considered as the most important collagen activation receptor on the platelet surface., ${ }^{7,8}$ Many studies have used convulxin, a snake venom toxin, to stimulate GPVI, but a major disadvantage of convulxin is the instability during its preanalytical storage. ${ }^{9}$ This excludes convulxin for clinical diagnostic use, unless the agonist can be modified to a stable compound. Other GPVI-specific agonists are synthetic collagen-related peptides (CRPs). Collagen contains large domains comprising Gly-X-Y repeats where $\mathrm{X}$ is often a proline $(\mathrm{P})$ and $\mathrm{Y}$ a 4-hydroxyproline $(\mathrm{O})$, and Farndale and colleagues discovered that the GPO repeats are important for the activation of GPVI. Monomeric CRP, a partial agonist of GPVI, stimulates the tyrosine phosphorylation of the tyrosine kinase Syk and phospholipase C gamma 2 in platelets and induces the weak secretion of [3H]5-hydroxytryptamine and a weak aggregation. ${ }^{10}$

Because collagen is folded into a unique triple-helical structure which is necessary for its activity, ${ }^{11}$ a triple-helical, crosslinked CRP (CRP-XL), was synthesized containing GPO repeats cross-linked through cysteine residues at its $\mathrm{N}$-terminus and Cterminus. CRP-XL is a powerful stimulus of tyrosine phosphorylation and platelet activation ( $\sim 100$-fold more potent than collagen on a weight-for-weight basis) but is unable to bind to $\alpha 2 \beta 1 .{ }^{12-14}$ CRP-XL is currently the first choice to quantify the most important collagen-dependent platelet activation pathway in flow cytometry because it is a stable and specific GPVI agonist. ${ }^{15-17}$ Despite the excellent intrabatch variation and the high stability in preanalytical conditions, CRP-XL has some variation between batches, which requires a calibration before a new batch can be used in a diagnostic setting. ${ }^{18,19} \mathrm{~A}$ further threat of using CRP-XL as standard for GPVI-dependent platelet function is the dependence on one (noncommercial) laboratory that can produce this agonist, making other laboratories depend on the supply of this laboratory.

We have designed a peptide with a primary sequence of the trimeric peptides identical to CRP-XL (GPC-(GPO) $10^{-}$ GPCG-amide $)_{3}$ with three helices connected by 1,3,5-tribromomesitylene (T3)-Clips on both termini of the triple helical peptides.

\section{Materials and Methods}

\section{GPVI-Specific Agonists}

CRP-XL was purchased from the Department of Biochemistry of the University of Cambridge, United Kingdom. The activity and specificity of the peptide has been extensively evaluated by many groups, including ourselves. ${ }^{15,20,21}$ We have designed and developed a novel peptide synthesis procedure based on our knowledge of the three-dimensional structure and sequence of CRP-XL (GPC-(GPO) ${ }_{10}$-GPCG-amide) 3 (-Fig. 1A). The peptide was synthesized at Pepscan (Lelystad, The Netherlands) following a stepwise procedure: peptide 1 $\left(\mathrm{C}_{\mathrm{SH}} \mathrm{G}(\mathrm{POG})_{10} \mathrm{PC} \mathrm{S}_{\mathrm{S}(\mathrm{Acm})}\right.$, where "O" = L-hydroxyproline, molecular weight $[\mathrm{MW}]=3163.7 \mathrm{Da}$ ) was dissolved in a $1: 1: 1$ mixture of $8 \mathrm{M}$ urea/acetonitrile (ACN)/N,N-dimethylformamide (DMF) to a concentration of $5.0 \mathrm{mM}$ (i.e., $15.8 \mathrm{mg} / \mathrm{mL}$ ). Subsequently, 0.25 equivalent of T3 in ACN $(125 \mu \mathrm{L}$ of a $10 \mathrm{mM}$ solution $/ \mathrm{mL}$ of peptide solution) was added, followed by $0.25 \mathrm{~mL}$ of a $200 \mathrm{mM}$ ammonium bicarbonate solution. The mixture was homogenized, incubated for 15 to 30 minutes at room temperature (RT), diluted in Milli- $Q$ water $(5-10 \times$ the original volume), and purified by preparative high-performance liquid chromatography (HPLC). The purified trimeric peptide T3-[1-(Acm) $]_{3}$ was then Acm-deprotected by dissolving the peptide in $8 \mathrm{M}$ guanidine- $\mathrm{HCl}$ to a concentration of $1.0 \mathrm{mM}$ (i.e., $9.7 \mathrm{mg} / \mathrm{mL}$ ), and $1.0 \mathrm{~mL}$ of this solution was mixed with $100 \mu \mathrm{L}$ of a $34 \mathrm{mg} / \mathrm{mL}$ solution of $\mathrm{I} 2$ in methanol. The reaction was stirred at RT for 30 to 60 minutes, quenched with $50 \mu \mathrm{L}$ of a $1.0 \mathrm{M}$ solution of 1,4-dithiothreitol followed by the addition of $260 \mu \mathrm{L}$ of an $0.2 \mathrm{M}$ sodium carbonate solution (until $\mathrm{pH}>7$ ), and again stirred for an additional 5 to 10 minutes at RT. The reaction mixture was then quenched with $10 \%$ of trifluoroacetic acid (TFA) until $\mathrm{pH}<3$ and diluted with 5 to 10 volumes of Milli-Q water (peptide product should not precipitate!) and purified by preparative HPLC.

The purified Acm-deprotected trimeric peptide T3-[1-(SH) $]_{3}$ was dissolved in a 1:1:1 mixture of $8 \mathrm{M}$ urea/ACN/DMF to a concentration of $0.1 \mathrm{mM}$ (i.e., $\sim 1.0 \mathrm{mg} / \mathrm{mL}$ ), and to $1.0 \mathrm{~mL}$ of this solution, $10 \mu \mathrm{L}$ of a $10 \mathrm{mM} \mathrm{T3}$ ( 1.1 equivalent) in $\mathrm{ACN}$ was added followed by the addition of $25 \mu \mathrm{L}$ of $200 \mathrm{mM}$ ammonium bicarbonate solution. The mixture was again homogenized and incubated for 15 to 30 minutes at RT and checked by analytical ultra-performance liquid chromatography/electrospray ionization mass spectrometry (UPLC/ESI-MS) to confirm completion of the reaction. Finally, the mixture was diluted in Milli- $\mathrm{Q}$ water (5-10 $\times$ the original volume) and purified by preparative HPLC to obtain the final double-CLIPS constrained trimeric peptide T3-[1] $]_{3}-\mathrm{T} 3$ in an overall yield of 1 to $2 \%^{22}$ The MS product 
Peptide-1: $\quad \mathrm{C}_{\mathrm{SH}} \mathrm{G}(\mathrm{POG})_{10} \mathrm{PC}_{\mathrm{S}(\mathrm{Acm})}$
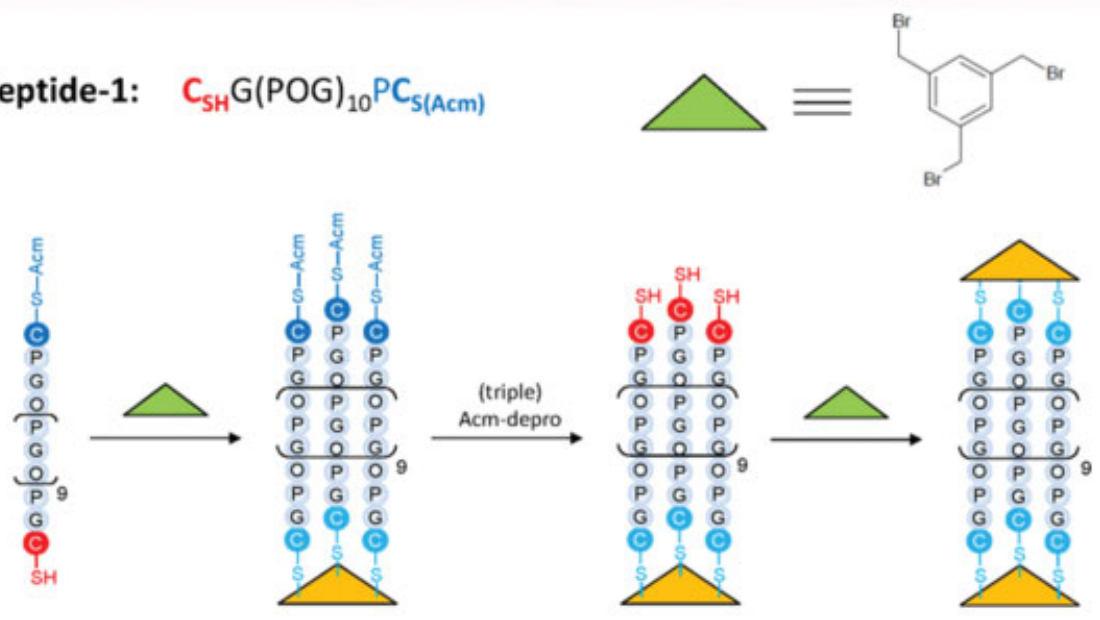

A

Peptide 1

T3- $\left(\mathrm{C}_{5} \text {-peptide1- } \mathrm{C}_{\mathrm{S}(\mathrm{ACM})}\right)_{3}$

T3-(C - -peptide1- $\left.\mathrm{C}_{\mathrm{SH}}\right)_{3}$

T3- $\left(C_{5}-\text { peptide1 }-C_{5}\right)_{3}-T_{3}$

M

MW:

T3-PTI-1218-T3-pr 321 (1.129) Cm (311:335)

100
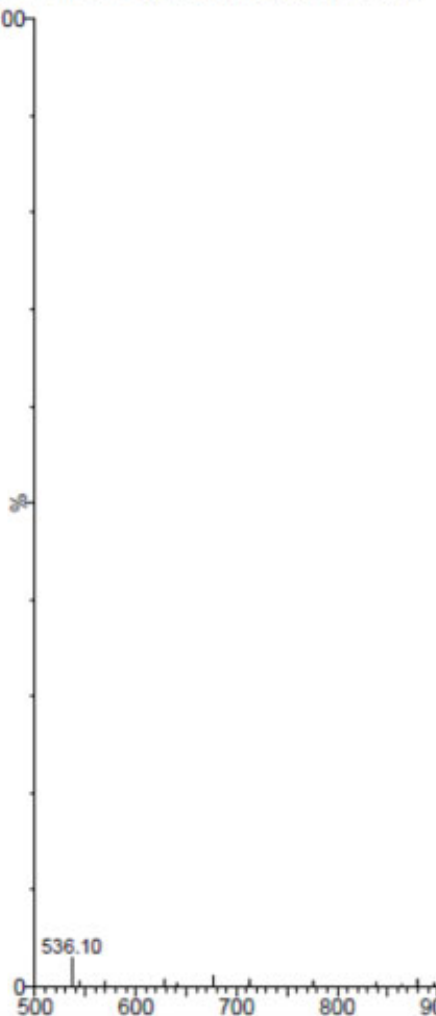

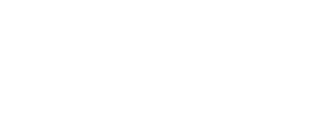

Fig. 1 Synthesis of synthetic triple helical collagen peptide (STH-CP) triple helical peptide. (A) Peptide $1\left[C_{S H} G(P O G){ }_{10} P C_{(A c m)}\right]$ was mixed with 0.25 equivalent of 1,3,5-tribromomesitylene (T3) and purified by preparative high-performance liquid chromatography (HPLC). The purified trimeric peptide T3-[1-(Acm) $]_{3}$ was Acm-deprotected to trimeric peptide T3-[1-(SH) $]_{3}$, which was mixed with 1:1 equivalents of T3. The mixture was checked by analytical ultra-performance liquid chromatography electrospray ionization mass spectrometry (UPLC/ESI-MS) to confirm completion of the reaction. Finally, the mixture was diluted in Milli-Q water (5-10× the original volume) and purified by preparative HPLC to obtain the final double-CLIPS constrained trimeric peptide T3-[1]3-T3. (B) Electron-spray ionization mass spectrometry (ESI-MS) spectrum of the UPLC-peak at $t_{R}=1.11$ minutes, showing the $[M+5 H] 5+$ signal at $m / z=1901.34$ as the main peak $(100 \%)$ and the $[M+6 H] 6+s i g n a l$ at $m /$ $z=1584.71$ in $25 \%$ intensity. From these signals, an $\mathrm{MW}_{\exp }=9502.2 \pm 1.5$ Da was calculated, which compares well with the theoretical molecular weight (MW) of 9503.1 Da that was calculated for this compound.

characterization data were: retention time (UPLC): 1.11 minutes ( $=32.75 \% \mathrm{ACN}$ ); 5 to $55 \%$ gradient of eluent-B in eluent-A; eluent-A: $0.05 \%$ TFA in Milli-Q water; eluent B: $0.05 \%$ TFA in CAN). Characterization of high-MW compounds by
ESI-MS goes via detection of multiple-charged ions in the $\mathrm{m} / \mathrm{z}$ range of 500 to 2,000 . The single-charged molecular ion is usually not observed, because ESI-MS machines typically do not measure ion currents at $>2,000$ Da. Thereby, it is not 
predictable which multicharged species is observed and in what amount; that is simply a characteristic of the molecule itself. As shown in - Fig. 1B, the molecule is mainly present as $5+$-charged species in the gas phase together with approximately $20 \%$ of the $6+$-charged species, while higher charged species are not observed (quite normal if there are not sufficient protonation sites available). On the other hand, any lower charged species $(4+, 3+, 2+)$ may be present as well, but have a $m / z$ ratio of $>2,000 \mathrm{Da}$ and are therefore not observed. ESI-MS: MW $_{\text {exp }}$ : $9502.2 \pm 1.5$ Da; MW $_{\text {calc }}$ : 9503.1 Da (-Fig. 1B).

\section{Reagents}

Platelet activation leads to expression of activation markers on the outer membrane of platelets, which can be quantified by the binding of antibodies, using flow cytometry. The antibodies used in the platelet activation test were fluorescein isothiocyanate (FITC)-conjugated monoclonal antibody procaspase-activating compound-1 (PAC-1) directed against the activated $\alpha$ IIb $\beta 3$ receptor, phycoerythrin (PE)-conjugated monoclonal antibody anti-P-selectin (CD62P, clone AK4), and allophycocyanin (APC)-conjugated anti-CD42b (GPIb) monoclonal antibody (clone HIP1), all purchased from BD Pharmingen (New Jersey, United States). Anti-mouse immunoglobulin (Ig) $\mathrm{K}$ particles and negative control (NC) particles were also purchased from BD Pharmingen.

\section{Preparation of the Platelet Activation Tests}

Platelet reaction mixture, with a volume of $20 \mu \mathrm{L}$, consisted of $2 \mu \mathrm{L}$ FITC-conjugated PAC-1, $1.5 \mu \mathrm{L}$ PE-conjugated anti-Pselectin, and $0.5 \mu \mathrm{L}$ APC-conjugated anti-CD42b with or without CRP-XL or synthetic triple helical collagen peptide (STH-CP) in HEPES-buffered saline (HBS, $10 \mathrm{mmol} / \mathrm{L}$ HEPES, $150 \mathrm{mmol} / \mathrm{L} \mathrm{NaCl}, 1 \mathrm{mmol} / \mathrm{L} \mathrm{MgSO}_{4}, 5$ mmol/L KCL, pH 7.4). Optimal peptide concentrations were determined in five healthy donors by testing a serial dilution of STH-CP and CRP-XL. Further tests were prepared with 30 and $5 \mu \mathrm{g} / \mathrm{mL}$ for STH-CP and CRP-XL, respectively. In each platelet activation test, three additional conditions were included to detect binding of antibodies to anti-mouse Ig $\mathrm{k}$ particles or NC particles. The NC condition contained $2 \mu \mathrm{L}$ FITC-conjugated PAC-1 and 1.5 $\mu \mathrm{L}$ PE-conjugated anti-P-selectin in HBS (total volume of $20 \mu \mathrm{L}$ ). Two positive control (PC) conditions were prepared: PC1 contained $2 \mu \mathrm{L}$ FITC-conjugated PAC-1 and PC2 contained $1.5 \mu \mathrm{L}$ PE-conjugated anti-P-selectin in HBS (total volume of $20 \mu \mathrm{L}$ ). Test strips were prepared in advance and stored at $-20^{\circ} \mathrm{C}$.

\section{Performing the Platelet Activation Tests}

Test strips were thawed and briefly centrifuged. All tests were performed at $37^{\circ} \mathrm{C}$. Whole blood was stored at RT for at least 30 minutes and a maximum of 4 hours, incubated at $37^{\circ} \mathrm{C}$ for 10 minutes and diluted $1: 4$ in preheated HBS to minimize the formation of platelet aggregates. From this diluted blood, $5 \mu \mathrm{L}$ were added to each reaction mixture (20 $\mu \mathrm{L}$, final dilution $1: 20$ ) and the tests were incubated for exactly 20 minutes. Simultaneously, $5 \mu \mathrm{L}$ of NC particles were added to the NC condition, and $5 \mu \mathrm{L}$ of anti-mouse Ig $\mathrm{K}$ particles were added to both PC1 and PC2. Reactions were stopped by adding $250 \mu \mathrm{L}$ fixation solution $(137 \mathrm{mmol} / \mathrm{L}$ $\mathrm{NaCl}, 2.7 \mathrm{mmol} / \mathrm{L} \mathrm{KCl}, 1.12 \mathrm{mmol} / \mathrm{L} \mathrm{NaH}_{2} \mathrm{PO}_{4}, 1.15 \mathrm{mmol} / \mathrm{L}$ $\mathrm{KH}_{2} \mathrm{PO}_{4}, 10.2 \mathrm{mmol} / \mathrm{L} \mathrm{Na}_{2} \mathrm{HPO}_{4}, 4 \mathrm{mmol} / \mathrm{L}$ EDTA, $0.5 \%$ formaldehyde).

Flow cytometry was used to discriminate platelets from other cells, using the forward and sideward scatter pattern and by gating on the CD42b positive cells. Fluorescent intensity in the FITC gate and PE gate was selected to determine activated $\alpha \operatorname{IIb} \beta 3$ and P-selectin density, respectively, and results are expressed as median fluorescent intensity (MFI).

In addition to flow cytometry, we investigated platelet response to CRP-XL $(5 \mu \mathrm{g} / \mathrm{mL})$, Horm collagen (2 and $5 \mu \mathrm{g} /$ $\mathrm{mL})$, and STH-CP $(30 \mu \mathrm{g} / \mathrm{mL})$ in platelet-rich plasma, using LTA.

\section{Study Population}

Our study protocol was evaluated by the local medical ethical board (Medical Ethical Committee of Maastricht University Medical Center). The study population consisted of 118 healthy adult individuals, aged 20 to 65 years. All participants did not take any oral anticoagulant or antiplatelet drugs for at least 2 weeks, did not have a history of thrombosis or bleeding, and gave full informed consent according to the Helsinki Declaration. Experiments were conducted at the Synapse Research Institute in accordance with approved guidelines and regulations. Blood was collected aseptically by antecubital puncture via a 21 -gauge needle $(0.8 \times 32 \mathrm{~mm})$ into vacuum tubes ( 1 volume trisodium citrate $0.105 \mathrm{M}$ to 9 volumes blood) (BD Vacutainer System/Greiner). The blood was kept at RT and used within 4 hours after collection. Cell counts in whole blood were performed with a Coulter Counter analyzer (Beckman Coulter, Woerden, The Netherlands).

\section{Statistics}

Beads were used to normalize the flow cytometric data with the following equation:

$$
100 \times\left(\mathrm{MFI}_{\mathrm{a}}-\mathrm{MFI}_{\mathrm{c}}\right) /\left(\mathrm{MFI}_{\mathrm{PC}}-\mathrm{MFI}_{\mathrm{NC}}\right)
$$

where $\mathrm{MFI}_{\mathrm{a}}$ was the MFI of the activated platelets, $\mathrm{MFI}_{\mathrm{c}}$ the MFI of the unstimulated platelets, $\mathrm{MFI}_{\mathrm{PC}}$ the MFI measured on the PC beads, and $\mathrm{MFI}_{\mathrm{NC}}$ the MFI of the NC beads.

For the reference values, outlier analysis was performed using the D/R method (Dixon). Three outliers were excluded (P-selectin expression in response to STH-CP and CRP-XL) by visual inspection. Normality was tested using the ShapiroWilk test and data were normally distributed after excluding the outliers. Mean and standard deviation (SD) were shown and interindividual variability (percent coefficient of variation [\%CV]) was calculated for each variable as $100 \times(\mathrm{SD} /$ mean $)$. Reference intervals were obtained using nonparametric calculation methods, in accordance with the recommendation in the latest Clinical and Laboratory 
Standards Institute guidelines. ${ }^{23}$ More precisely, the lower reference interval limit was estimated as the 2.5 th percentile, and the upper limit as the 97.5th percentile of the distribution. Groups were compared using the Mann-Whitney $U$ test for independent samples.

Data of the repeated measurements over a 1-year period were expressed as mean \pm SD and statistical significance was tested using Tukey's multiple comparisons.

\section{Results}

\section{Dose-Dependent Response of Platelets on STH-CP}

An optimal concentration of STH-CP and CRP-XL to activate platelets was determined by testing a serial dilution of STH-CP and CRP-XL in fresh blood from five healthy donors in triplicate. For each donor, these experiments were executed on a single day, using the same batch of platelet function tests. As shown in - Fig. 2, the activation of $\alpha$ IIb $\beta 3$ receptor and the expression of P-selectin increased in a dose-dependent manner and optimal concentration of $30 \mathrm{and} 5 \mu \mathrm{g} / \mathrm{mL}$ were chosen for STH-CP and CRP-XL, respectively. To confirm the potency of STH-CP, STH-CP ( $30 \mu \mathrm{g} / \mathrm{mL})$ and CRP-XL $(5 \mu \mathrm{g} / \mathrm{ml})$ were used in LTA to activate platelets and comparable platelet aggregation was observed ( - Supplementary Fig. $\mathbf{5 1}$, available in the online version).

The Precision of Platelet Activation Induced by STH-CP To obtain intra-assay precision data of platelet activation tests, we performed replicate experiments $(n=10)$ in three healthy donors. For each donor, these experiments were executed on a single day, using the same batch of platelet function tests. Platelets were activated with CRP-XL $(5 \mu \mathrm{g} / \mathrm{mL})$ or STH-CP $(30 \mu \mathrm{g} / \mathrm{mL})$, incubated with FITCconjugated PAC-1 and PE-conjugated anti-P-selectin, and MFI were measured to determine $\alpha$ IIb $\beta 3$ receptor activation and P-selectin expression on the platelet membrane, respectively. Comparable results were found for both STH-CP and CRP-XL and the intra-assay variability was well below $5 \%$ for both $\alpha$ IIb $\beta 3$ receptor activation and P-selectin expression (-Table $\mathbf{1})$.

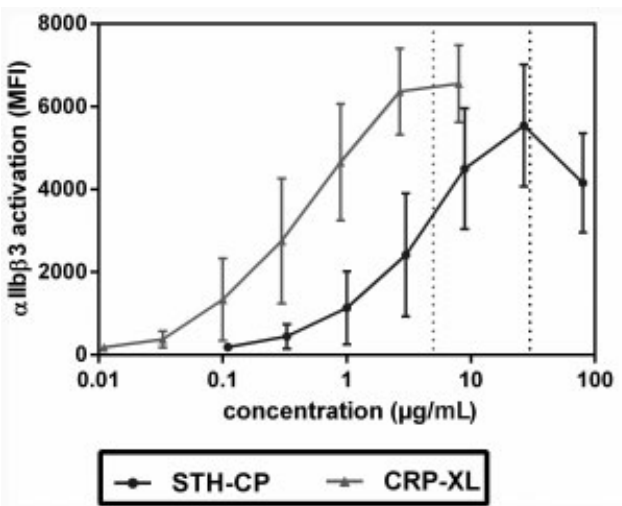

Table 1 Intra-assay variability of the platelet function test

\begin{tabular}{|c|l|l|l|l|}
\hline & \multicolumn{4}{|l|}{ Intra-assay variability (\%CV) } \\
\hline & Donor 1 & Donor 2 & Donor 3 & Mean \\
\hline & $(\boldsymbol{n}=\mathbf{1 0})$ & $(\boldsymbol{n}=\mathbf{1 0})$ & $(\boldsymbol{n}=\mathbf{1 0})$ & $\%$ CV \\
\hline allb33 activation & & & & \\
\hline STH-CP & 2.5 & 4.0 & 2.8 & 3.1 \\
\hline CRP-XL & 2.7 & 2.5 & 2.1 & 2.4 \\
\hline $\begin{array}{l}\text { P-selectin } \\
\text { expression }\end{array}$ & & & & \\
\hline STH-CP & 3.0 & 4.0 & 2.6 & 3.2 \\
\hline CRP-XL & 2.6 & 1.8 & 1.9 & 2.1 \\
\hline
\end{tabular}

Abbreviations: \%CV, percent coefficient of variation; CRP-XL, cross-linked collagen-related peptide; STH-CP, synthetic triple helical collagen peptide.

\section{STH-CP Induced Platelet Activation in a Healthy Population}

In total, platelet activation in response to STH-CP was measured in 118 healthy individuals. Demographic data of 115 healthy individuals ( 53 females and 62 males, median 33 years) together with blood counts are summarized in - Table 2 (data of three donors were missing). In our population, there were significantly more men than women. The hemoglobin levels, hematocrit, and red blood cell counts were significantly higher while the platelet count was significantly lower in men compared with women.

The interindividual variability (\%CV) as well as reference intervals (2.5-97.5 percentile) were determined for P-selectin expression and $\alpha$ IIb $\beta 3$ receptor activation in response to STH-CP and CRP-XL in 118 healthy volunteers (-Table 3). For P-selectin expression, data of three donors were determined as outliers. Apart from the reference values, medians, interquartile ranges, minimum and maximum values of each test parameter are indicated. The interindividual variation of platelet function in response to STH-CP and CRP-XL was comparable and within acceptable ranges with mean \%CV of 23.1 and $20.9 \%$ for $\alpha$ IIb $\beta 3$ receptor activation and P-selectin expression, respectively.

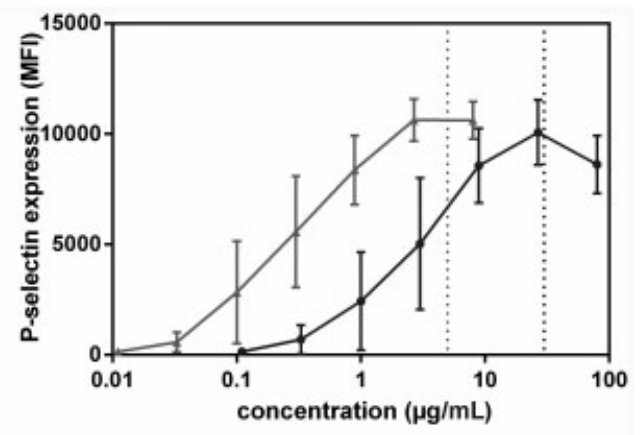

Fig. 2 Determining optimal concentrations for synthetic triple helical collagen peptide (STH-CP) and cross-linked collagen-related peptide (CRP$\mathrm{XL}$ ). Whole blood of 5 donors was incubated for 10 minutes at $37^{\circ} \mathrm{C}$ and, subsequently, platelets were activated for 20 minutes at $37^{\circ} \mathrm{C}$ with STH$\mathrm{CP}$ (red) and CRP-XL (blue). Dose-dependent activation curves were created for both $\alpha$ llb $\beta 3$ receptor activation (left panel) and P-selectin expression (right panel). The dotted line represents the concentration of the agonists used in the subsequent experiments. 
Table 2 Baseline data of 115 healthy individuals

\begin{tabular}{|l|l|l|l|l|}
\hline & All & Women $(\boldsymbol{n}=53)$ & Men $(\boldsymbol{n}=62)$ & $p$-Values \\
\hline Age, years & $33(27-49)$ & $41(30-51)$ & $31(26-44)$ & 0.012 \\
\hline Hemoglobin, mmol/L & $9.1(8.3-9.8)$ & $8.5(8.0-8.9)$ & $9.8(9.5-10.2)$ & $<0.0001$ \\
\hline Hematocrit, $\%$ & $43(39-47)$ & $40(38-42)$ & $47(45-49)$ & $<0.0001$ \\
\hline Red blood cell count, ${ }^{*} 10^{12} / \mathrm{L}$ & $5.1(4.6-5.4)$ & $4.7(4.4-5,0)$ & $5.3(5.1-5.7)$ & $<0.0001$ \\
\hline Platelet count, ${ }^{*} 10^{9} / \mathrm{L}$ & $283(248-344)$ & $304(268-368)$ & $276(240-331)$ & 0.035 \\
\hline White blood cell count, ${ }^{*} 10^{9} / \mathrm{L}$ & $5.8(5.0-7.0)$ & $5.9(5.2-7.0)$ & $5.8(5.0-7.0)$ & $\mathrm{ns}$ \\
\hline
\end{tabular}

Note: Medians and interquartile ranges (25-75\%) are indicated.

Table 3 Interindividual variation and reference intervals of the platelet function test

\begin{tabular}{|c|l|l|l|l|l|l|l|}
\hline & $N$ & Mean (\% of beads) & SD & \%CV & Reference interval (2.5-97.5\%) & Min & Max \\
\hline allb $\beta 3$ activation & & & & & & & \\
\hline STH-CP & 118 & 29.3 & 6.9 & 23.5 & $17.1-47.7$ & 12.0 & 49.8 \\
\hline CRP-XL & 118 & 30.9 & 7.0 & 22.7 & $17.5-49.1$ & 14.2 & 51.7 \\
\hline P-selectin expression & & & & & & & \\
\hline STH-CP & 115 & 14.8 & 3.1 & 20.9 & $7.3-22.0$ & 4.6 & 23.8 \\
\hline CRP-XL & 115 & 15.7 & 3.3 & 21.0 & $9.0-23.5$ & 5.7 & 24.7 \\
\hline
\end{tabular}

Abbreviations: \%CV, percent coefficient of variation; CRP-XL, cross-linked collagen-related peptide; SD, standard deviation; STH-CP, synthetic triple helical collagen peptide.
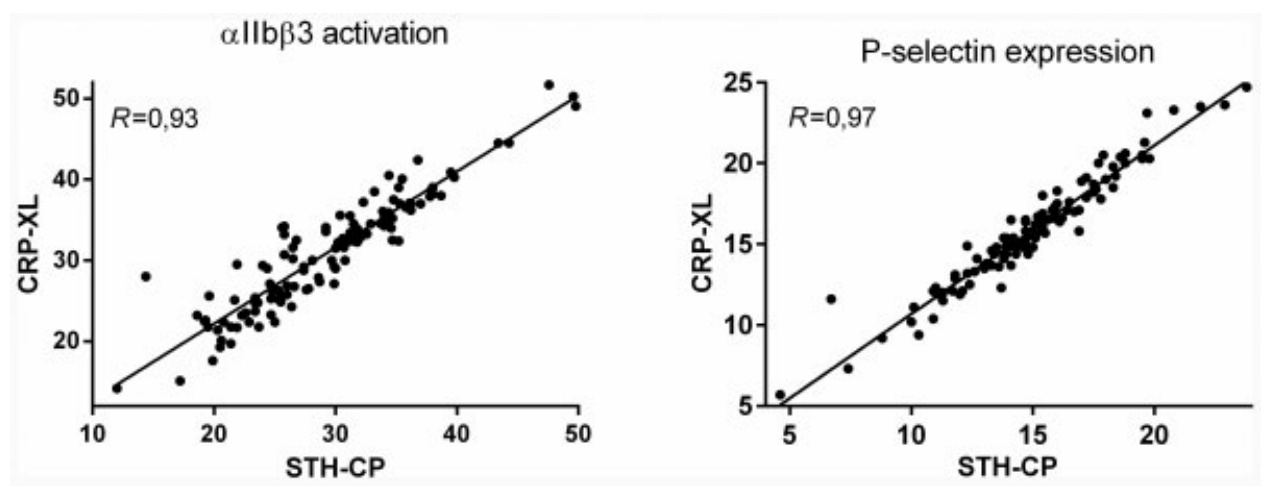

Fig. 3 Correlation of synthetic triple helical collagen peptide (STH-CP) and cross-linked collagen-related peptide (CRP-XL) for determining platelet function. Platelet function was measured as $\alpha$ llb $\beta 3$ activation (left panel) and P-selectin expression (right panel). The Pearson's coefficient is depicted.

\section{Correlation between Platelet Activation Responses to STH-CP and CRP-XL}

Platelet activation induced by STH-CP and CRP-XL was strongly correlated with correlation coefficients of $r=0.93$ $(p<0.0001)$ and $r=0.97(p<0.0001)$ for $\alpha$ IIb $\beta 3$ activation and P-selectin expression, respectively (-Fig. $\mathbf{3}$ ).

\section{Stability of Peptides during Freezer Storage}

To investigate the stability of the stored peptides in time, platelet function was measured every month in 10 donors over a 1-year period. Upon collection of blood, platelets were activated with STH-CP or CRP-XL, activated markers were measured and normalized data calculated (-Fig. 4). $\alpha I I b \beta 3$ receptor activation in response to $\mathrm{STH}-\mathrm{CP}$ was stable over the whole year. For CRP-XL, $\alpha$ IIb $\beta 3$ receptor activation was the lowest with mean value of 18.7 in May and highest in July with mean value of 27.4. Concerning P-selectin expression, the lowest and highest value in response to STH-CP/CRP-XL were detected in February (mean of 19.5/ 19.6) and August (mean of 23.9/25.5), respectively. Significant differences between the months are shown in detail in -Fig. 4.

The seasonal variation in response to the two GPVIspecific peptides is also shown in -Table 4. Compared with CRP-XL, the variation in a 1 -year period was lower when platelet activation was induced by STH-CP with \% CV of 5.3 and $6.6 \%$ for $\alpha \operatorname{IIb} \beta 3$ receptor activation and P-selectin expression, respectively. Between STH-CP and CRP-XL, strong correlations were found with correlation coefficients of $r=0.84(p=0.0003)$ and $r=0.91(p<0.0001)$ for $\alpha$ IIbß3 activation and P-selectin expression when measured every month during a year in 10 donors, respectively (-Fig. 5).

The conclusion of comparison between STH-CP and CRP$\mathrm{XL}$ is summarized in - Table $\mathbf{5}$. 

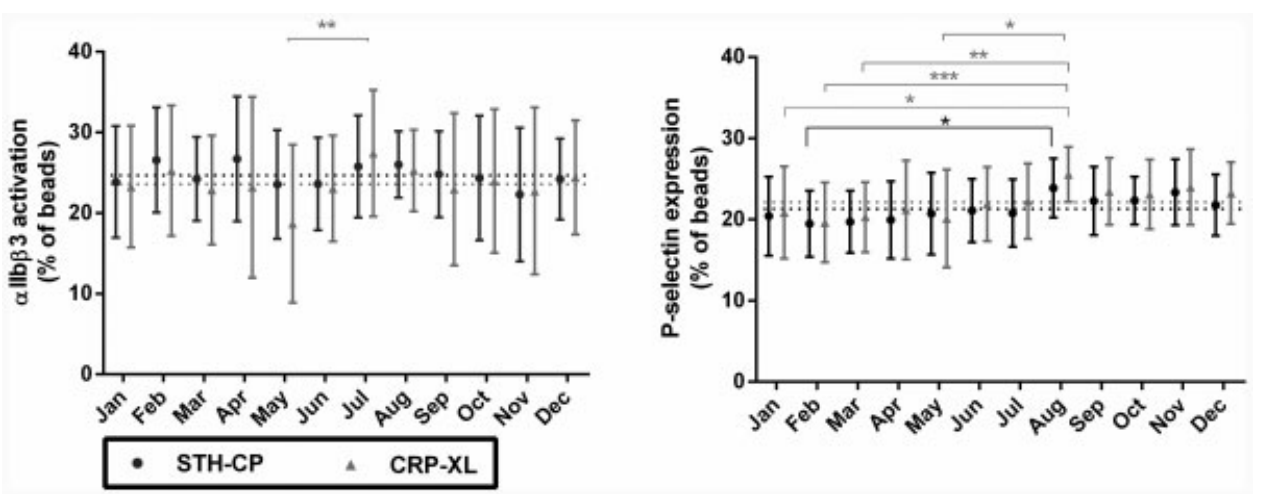

Fig. 4 Seasonal variation in platelet activation in response to synthetic triple helical collagen peptide (STH-CP) and cross-linked collagen-related peptide (CRP-XL). Every month during a 1-year period, platelet activation in response to STH-CP and CRP-XL were measured in 10 healthy donors and the data for both $\alpha$ llbB3 receptor activation (left panel) and P-selectin expression (right panel) were normalized using the negative control (NC) and positive control (PC) beads. Data were expressed as mean \pm standard deviation (SD). Differences between the groups were analyzed by Friedman test, followed by Dunn's multiple comparison test. ${ }^{*} p<0.05,{ }^{* *} p<0.01,{ }^{* * *} p<0.001$.

Table 4 Seasonal variation of the platelet function test

\begin{tabular}{|c|c|c|c|c|}
\hline & $N$ & $\begin{array}{l}\text { Mean } \\
\text { (\% of beads) }\end{array}$ & SD & $\% \mathrm{CV}$ \\
\hline \multicolumn{5}{|c|}{$\alpha$ llb $\beta 3$ activation } \\
\hline STH-CP & 10 & 24.7 & 1.3 & 5.3 \\
\hline CRP-XL & 10 & 23.6 & 2.1 & 8.9 \\
\hline \multicolumn{5}{|c|}{ P-selectin expression } \\
\hline STH-CP & 10 & 21.3 & 1.4 & 6.6 \\
\hline CRP-XL & 10 & 22.1 & 1.8 & 8.1 \\
\hline
\end{tabular}

Abbreviations: \%CV, percent coefficient of variation; CRP-XL, crosslinked collagen-related peptide; SD, standard deviation; STH-CP, synthetic triple helical collagen peptide.

\section{Discussion}

We studied the performance of a novel STH-CP on platelet function, ${ }^{15}$ and compared it with the performance of widely used cross-linked triple helical CRPS (CRP-XL). The unique property of STH-CP is that peptides are first coupled to a T3
Table 5 Comparison between STH-CP and CRP

\begin{tabular}{|l|l|l|}
\hline Item & STH-CP & CRP-XL \\
\hline Potency & ++ & +++ \\
\hline Precision & +++ & +++ \\
\hline Stability & +++ & ++ \\
\hline GPVI activation & +++ & +++ \\
\hline
\end{tabular}

Abbreviations: CRP-XL, cross-linked collagen-related peptide; STH-CP, synthetic triple helical collagen peptide.

Note: GPVI activation, reference intervals for $\alpha$ llb $\beta 3$ activation and Pselectin expression; Precision, intra-assay variability and interindividual variation; Reactivity, dose-dependent response curve; Stability, seasonal variation.

scaffold and then coupled to a second T3 staple which benefits from a proximity effect since all three peptides to be connected, reside within one molecule.

Many in vitro diagnostic platelet function tests, including LTA, use collagen fibrils, extracted from equine tendon, to measure platelet function. This type of collagen is poorly $\alpha \operatorname{llb} \beta 3$ activation

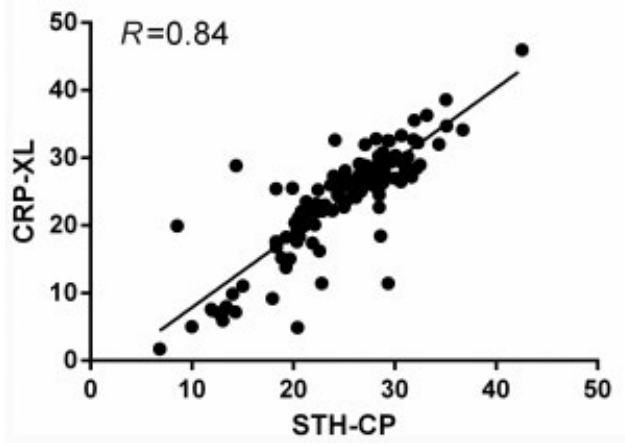

P-selectin expression

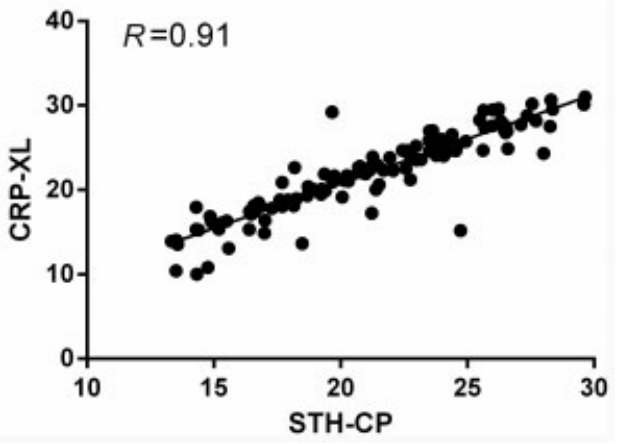

Fig. 5 Correlation of synthetic triple helical collagen peptide (STH-CP) and cross-linked collagen-related peptide (CRP-XL) for determining platelet function. Platelet function was measured in response to STH-CP and CRP-XL in 10 healthy donors every month during a 1-year period. The Spearman's coefficient is depicted for $\alpha$ llb $\beta 3$ activation (left panel) and P-selectin expression (right panel). 
defined, has a bad interbatch reproducibility, and, most probably, it does not represent the human collagens in the blood vessels, because the effects of fibrillar collagen on platelet activation depends on secondary structure of the collagen fibers. ${ }^{24}$ Despite the fact that the evidence for the specificity and the generalizability for human collagens are debatable, horse tendon collagen has developed as the gold standard for collagen function testing in diagnostic settings. This may have led to a systematic biased diagnosis of collagen-dependent platelet dysfunction for many decades. In our view, collagen mimetic peptides, specific for binding and activation of the most important platelet collagen receptors integrin $\alpha 2 \beta 1$ and GPVI, may be a more specific and better reproducible alternative for the collagen variant from equine tendon extracts.

When comparing the efficacy of STH-CP and CRP-XL to platelet activation response, we found that the activity pattern was identical, although the CRP-XL required sixfold lower concentrations than STH-CP to come to the same platelet activation state. This difference may be caused by the tight binding configuration between the two T3-Clips, which may influence the binding of the peptide to GPVI. Although sixfold higher concentrations of STH-CP are required for complete activation of platelets, the performance on platelet function measurements with flow cytometry and LTA show a reproducible agreement between STH-CP and CRP-XL. Therefore, we are convinced that our data show that STH-CP is not inferior to CRP-XL with regard to platelet activation research.

We determined reference values for platelet response to CRP-XL and STH-CP in 118 healthy volunteers. The platelet activation response to both triggers showed a strong correlation (Pearson's correlation of 0.93 for $\alpha$ IIb $\beta 3$-activation and of 0.97 for P-selectin expression). Furthermore, we showed that both STH-CP and CRP-XL have very high precision (both intra-assay \%CVs are below 5\%). Furthermore, both tests distinguish between individuals (interindividual \%CVs for both tests between 20 and 24\%). These observations were in agreement with a previous study on CRP-XL performance in 120 healthy volunteers. ${ }^{15}$

The stability of STH-CP during storage at $-20^{\circ} \mathrm{C}$ in readyto-use reaction mixtures was tested every month over a whole year. The correlations for platelet activation between both peptides were very high and this indicates that STH-CP and CRP-XL are most likely directed against the same platelet receptor, which has been established as GPVI for CRP-XL. The performance of both peptides is very good: CRP-XL seems a little bit more efficient, as indicated by the lower concentrations required to trigger platelet activation, while STH-CP seems a little bit more stable, as indicated by the lower variation over 12 months.

In summary, we have shown that STH-CP is stable and that the agonist gives reproducible platelet activation patterns, similar to CRP-XL. At the moment, the production of STH-CP is not yet optimized for large quantities, while production of different batches of STH-CP is required for validation studies to investigate the variation between different batches of STH-CP. These issues need to be solved before STH-CP can be used as an alternative for CRP-XL as trigger for platelet activation in in vitro diagnostic devices.

\section{What is known about this topic?}

- In hemostasis laboratory, collagen-related peptide (CRP-XL) is a valuable tool in platelet function tests for studying the interaction with the subendothelial collagen, intracellular signal events, and functional interplay between receptors. Currently, there is only one laboratory, which is capable of producing this valuable peptide for clinical applications.

\section{What does this paper add?}

- We developed a new synthetic triple helical collagen peptide (STH-CP) as alternative for CRP-XL, which was both on the C-terminus and on the $\mathrm{N}$-terminus fixed on a scaffold with a binding side for each of the three peptides.

- Compared with the known CRP-XL, this new STH-CP can induce comparable platelet activation response.

\section{Funding}

This work was performed at the Synapse Research Institute. Y.S. was supported by the China Scholarship Council (CSC) via the State Scholarship Fund (File No. 201606790009).

\section{Conflict of Interest}

Y.S. reports grants from China Scholarship Council during the conduct of the study. D.H., B.d-L. and M.R. are employees of the research company Synapse BV (member of the Diagnostica Stago Group).

\section{Acknowledgments}

The authors would like to thank S. Bloemen, S. Zwaveling, H. Kelchtermans, and C. Kicken for their help with blood drawings.

\section{References}

1 de Groot PG, Urbanus RT, Roest M. Platelet interaction with the vessel wall. Handb Exp Pharmacol 2012;(210):87-110

2 Cattaneo M, Cerletti C, Harrison P, et al. Recommendations for the standardization of light transmission aggregometry: a consensus of the working party from the platelet physiology subcommittee of SSC/ISTH. J Thromb Haemost 2013;11:1183-1189

3 Knight CG, Farndale RW. Peptide Synthesis in the Study of Collagen-Platelet Interactions. In: Walker JM, ed. New Jersey: Humana Press Inc.; 2004:490

4 Corredor C, Wasowicz M, Karkouti K, Sharma V. The role of pointof-care platelet function testing in predicting postoperative bleeding following cardiac surgery: a systematic review and meta-analysis. Anaesthesia 2015;70(06):715-731

5 Michelson AD. Evaluation of platelet function by flow cytometry. Pathophysiol Haemost Thromb 2006;35(1-2):67-82

6 van Asten I, Schutgens REG, Baaij M, et al. Validation of flow cytometric analysis of platelet function in patients with a 
suspected platelet function defect. JThromb Haemost 2018;16 (04):689-698

7 Clemetson JM, Polgar J, Magnenat E, Wells TN, Clemetson KJ. The platelet collagen receptor glycoprotein VI is a member of the immunoglobulin superfamily closely related to FcalphaR and the natural killer receptors. JBiol Chem 1999;274(41): 29019-29024

8 Nieswandt B, Watson SP. Platelet-collagen interaction: is GPVI the central receptor? Blood 2003;102(02):449-461

9 Kanaji S, Kanaji T, Furihata K, Kato K, Ware JL, Kunicki TJ. Convulxin binds to native, human glycoprotein Ib alpha. JBiol Chem 2003;278(41):39452-39460

10 Asselin J, Knight CG, Farndale RW, Barnes MJ, Watson SP. Monomeric (glycine-proline-hydroxyproline) 10 repeat sequence is a partial agonist of the platelet collagen receptor glycoprotein VI. Biochem J 1999;339(Pt 2):413-418

11 Prockop DJ, Kivirikko KI. Collagens: molecular biology, diseases, and potentials for therapy. Annu Rev Biochem 1995;64:403-434

12 Morton LF, Hargreaves PG, Farndale RW, Young RD, Barnes MJ. Integrin $\alpha 2 \beta$ 1-independent activation of platelets by simple collagen-like peptides: collagen tertiary (triple-helical) and quaternary (polymeric) structures are sufficient alone for $\alpha 2 \beta$ 1-independent platelet reactivity. Biochem J 1995;306 (Pt 2):337-344

13 Achison M, Joel C, Hargreaves PG, Sage SO, Barnes MJ, Farndale RW. Signals elicited from human platelets by synthetic, triple helical, collagen-like peptides. Blood Coagul Fibrinolysis 1996;7 (02):149-152

14 Asselin J, Gibbins JM, Achison M, et al. A collagen-like peptide stimulates tyrosine phosphorylation of syk and phospholipase $C \gamma 2$ in platelets independent of the integrin $\alpha 2 \beta 1$. Blood 1997;89(04): 1235-1242

15 Huskens D, Sang Y, Konings J, et al. Standardization and reference ranges for whole blood platelet function measurements using a flow cytometric platelet activation test. PLoS One 2018;13(02): e0192079

16 Polanowska-Grabowska R, Gibbins JM, Gear AR. Platelet adhesion to collagen and collagen-related peptide under flow: roles of the $[\alpha] 2[\beta] 1$ integrin, GPVI, and Src tyrosine kinases. Arterioscler Thromb Vasc Biol 2003;23(10):1934-1940

17 Knight CG, Morton LF, Onley DJ, et al. Collagen-platelet interaction: Gly-Pro-Hyp is uniquely specific for platelet Gp VI and mediates platelet activation by collagen. Cardiovasc Res 1999; 41(02):450-457

18 Lombardi F, De Chaumont C, Shields DC, Moran N. Platelet signalling networks: pathway perturbation demonstrates differential sensitivity of ADP secretion and fibrinogen binding. Platelets 2012;23(01):17-25

19 Garner SF, Furnell A, Kahan BC, et al. Platelet responses to agonists in a cohort of highly characterised platelet donors are consistent over time. Vox Sang 2017;112(01):18-24

20 Kicken CH, Roest M, Henskens YM, de Laat B, Huskens D. Application of an optimized flow cytometry-based quantification of Platelet Activation (PACT): monitoring platelet activation in platelet concentrates. PLoS One 2017;12(02):e0172265

21 Roest M, van Holten TC, Fleurke GJ, Remijn JA. Platelet activation test in unprocessed blood (Pac-t-UB) to monitor platelet concentrates and whole blood of thrombocytopenic patients. Transfus Med Hemother 2013;40(02):117-125

22 Timmerman P, Puijk WC, Meloen RH. Functional reconstruction and synthetic mimicry of a conformational epitope using CLIPS technology. J Mol Recognit 2007;20(05):283-299

23 LSI. Measurement Procedure Comparison and Bias Estimation Using Patient Samples; Approved Guideline-Third Edition. CSLI Doc. EP093A 33, (2013)

24 Savage B, Ginsberg MH, Ruggeri ZM. Influence of fibrillar collagen structure on the mechanisms of platelet thrombus formation under flow. Blood 1999;94(08):2704-2715 